\title{
Characterisation of the spoilage microbiota in raw salmon (Salmo salar) steaks stored under vacuum or modified atmosphere packaging combining conventional methods and PCR-TTGE
}

\author{
Sabrina Macé ${ }^{\mathbf{a}, \mathbf{b}, \mathbf{c}}$, Josiane Cornet $^{\mathbf{c}}$, Frédérique Chevalier ${ }^{\mathbf{c}}$, Mireille Cardinal $^{\mathbf{c}}$, Marie-France Pilet ${ }^{\mathbf{a}, \mathbf{b}}$, \\ Xavier Dousset ${ }^{\mathbf{a}, \mathbf{b}}$, Jean-Jacques Joffraud ${ }^{\mathbf{c},{ }^{*}}$ \\ a LUNAM Université, Oniris, Univ Nantes, UMR 1014 Secalim, Nantes, F-44307, France \\ ${ }^{b}$ INRA, Nantes, F-44307, France \\ ${ }^{c}$ Ifremer, Laboratoire Science et Technologie de la Biomasse Marine, BP 21105, 44311 Nantes Cedex 3, France
}

*: Corresponding author : Jean-Jacques Joffraud : Tel.: +33240374284 ; fax: +332 40374071. ;

email address : jean.jacques.joffraud@ifremer.fr

\begin{abstract}
:
In order to characterise the spoilage related to microbiota of raw salmon, a combination of culturedependent and -independent methods, including PCR-TTGE, was used to analyse 3 raw salmon batches stored for 3 days at chilled temperature in modified atmosphere packaging (MAP) (50\% $\mathrm{CO}_{2} / 50 \% \mathrm{~N}_{2}$ ) or under vacuum. Sensory evaluation, microbiological enumeration and chemical analysis were performed after 3,7 and 10 days of storage. At the onset of spoilage, 65 bacterial isolates were picked from the plates. Thus, 13 different genera or species were identified by phenotypic and molecular tests: Serratia spp., Photobacterium phosphoreum, Yersinia intermedia, Hafnia alvei, Buttiauxella gaviniae, Pseudomonas sp., Carnobacterium maltaromaticum, Carnobacterium divergens, Lactococcus piscium, Lactobacillus fuchuensis, Vagococcus carniphilus, Leuconostoc gasicomitatum and Brochothrix thermosphacta. The PCR-TTGE profiles and band identification enabled a shift of the dominant populations during the storage to be visualised for all the batches, probably due to the temperature change and the packaging. At the beginning of storage, Pseudomonas sp. dominated the raw salmon microbiota while in the following days (7 and 10), $P$. phosphoreum and $L$. piscium were identified as the main bacterial groups. This study enhances the knowledge of MAP and vacuum-packed raw salmon spoilage microbiota.
\end{abstract}

\section{Highlights}

13 different bacterial taxa were identified by phenotypic and molecular tests. A shift of the dominant microflora during storage was brought to light. - The dominant bacterial populations displayed by PCR-TTGE were identified.

Keywords : Seafood; Culture-independent method (PCR-TTGE); Sensory analysis; Photobacterium phosphoreum; Lactococcus piscium 


\section{Introduction}

Salmon is an important product of aquaculture: 1,400,000 T were produced in 2009 with a value of more than 7 billion US dollars (FAO, 2011). The species studied in this work, Atlantic salmon (Salmo salar), is the one most commonly reared. Atlantic salmon farming accounts for $90 \%$ of the farmed salmon market and more than $50 \%$ of the global salmon market (FAO. (C) 2004-2011. Texte par Jones, 2004). Moreover, chilled fish has significant added value compared to frozen fish (Fletcher, et al., 2002). Sea fish is increasingly eaten raw (sushi, tartare) and, in response to consumer demand, these products are found on cold shelves under modified atmosphere packaging (MAP) enriched with $\mathrm{CO}_{2}$. This type of packaging increases the shelf life of seafood products by inhibiting many microorganisms, including Gram-negative aerobic microorganisms (Gram \& Huss, 1996; Sivertsvik, et al., 2002)), and also makes transport easier. Even though MAP increases the package volume compared to vacuum packaging, it is more efficient at limiting the spoilage (Hansen, et al., 2007). Some studies concerning Atlantic or King salmon under MAP have been carried out to determine quality changes during storage or to propose some technological features to improve the shelf life (de la Hoz, et al., 2000; Fletcher, et al., 2002; Hansen, et al., 2009; Schirmer, et al., 2009; Sivertsvik, et al., 2003). In these studies, the changes in microbial parameters, such as total flora, Enterobacteriaceae, and Lactic Acid Bacteria (LAB), were usually monitored during storage but the detailed composition of the microbiota has been investigated only once (Rudi, et al., 2004). The characterisation of the microbial species present at the spoilage time is important to determine which are likely to be involved in sensory quality deterioration and should thus be considered as specific spoilage microorganisms in further studies in order to develop suitable control methods. For this characterisation, applications of culture-independent methods are being increasingly used in parallel with classical microbial methods to develop a complete overview of the bacterial community characteristics. Fingerprinting molecular methods, such as DGGE and TTGE, are powerful tools to compare structural changes in microbial communities as well as for monitoring bacterial population dynamics. Individual bands can be identified after excision from the gel, cloning and sequencing (Juste, et al., 2008). Bands can also be assigned and identified by comparison with a comprehensive bacterial database that should include microorganisms typical of the ecosystem (Ogier, et al., 2004). The use of culture-independent methods has highlighted the occurrence of species not detected by culture-based methods. Several food product microbiota have been analysed with DGGE or TTGE, including dairy product ecosystems (Lafarge, et al., 2004; Ogier, et al., 2004; Ogier, et al., 2002; Parayre, et al., 2007), chilled beef stored in air or vacuum (Pennacchia, et al., 2011), seafood products like cold smoked salmon (Giacomazzi, et al., 2004; Rachman, et al., 2004), fish (Hovda, et al., 2007) and cooked tropical shrimps (Jaffrès, et al., 2009). In this present study, our aim was to monitor the changes in shelf life and quality and to characterise the microbial ecosystem of 3 raw salmon (Salmo salar) batches stored under MAP and vacuum with a combination of complementary methods: molecular, sensory, chemical and conventional microbiological analyses. Sensory analysis was used to identify when the product was spoiled. The spoilage microbiota of these 3 batches were described using classical numeration on different specific media used for fish bacteria analysis and the PCR-TTGE technique was employed to monitor the dominant bacterial populations and their changes during storage. 


\section{Materials and methods}

\subsection{Raw salmon sampling}

Two batches of raw salmon steaks (Salmo salar), A and B, processed from the same raw material, were purchased from one production plant and one batch $C$ came from another production plant. A and $C$ were packaged under MAP $\left(50 \% \mathrm{CO}_{2}-50 \% \mathrm{~N}_{2}\right)$ and $\mathrm{B}$ under vacuum. Samples were stored for 3 days at $2^{\circ} \mathrm{C}$ and transferred to $8^{\circ} \mathrm{C}$ for 7 days after a cold chain break at $20^{\circ} \mathrm{C}$ for 2 hours, according to the shelf life evaluation protocol monitored by industrial plants. Sensory evaluation and microbiological analyses, including culture and nonculture methods, were carried out at days 3,7 and 10.

\subsection{Sensory analysis}

Eleven trained panellists, experienced in seafood sensory evaluation, carried out the conventional profiling (ISO, 2003) on salmon products. Three packets per batch were opened and, for each assessor, $30 \mathrm{~g}$ portions were placed in glass bowls to keep the odours intact. Sessions were performed in individual partitioned booths, as described in the procedure NF V-09-105 (AFNOR, 1987), equipped with a computerised system (Fizz, Biosystèmes, Couternon, France). Three sessions were organised after 3,7 and 10 days of storage, respectively. Products $A, B$ and $C$ were assigned 3 digit numbers, randomised and presented simultaneously to the panellist after 1 hour in an oven at $18^{\circ} \mathrm{C}$. Assessors had to score overall intensity on a continuous scale from 0 to 10 of the following appropriate odour descriptors: marine/iodine, grass, butter/caramel, acid/vinegar, sour/fermented, amine and feet/cheese. At the end of the evaluation, panellists classified each sample according to its spoilage level (NS: non-spoiled; LS: lightly spoiled; SS: strongly spoiled). The products were considered to be strongly spoiled when at least $50 \%$ of the assessors classified them at this level.

The sensory descriptors were selected during preliminary sessions. Panellists were first invited to describe the odour characteristics of three products processed in the two production plants of the study and stored 2, 8 and 12 days in the conditions previously presented. These samples intended to cover the possible variation of sensory characteristics in this kind of samples. After a selection of relevant and discriminative attributes, a discussion with all panellists allowed to check the final consensus on descriptors. Two profiling sessions were also proposed to train the panel and evaluate its performance before to start the experiment.

Two-way analyses of variance, with products and panellists as independent factors, were performed on sensory data with Fizz 2.46B software (FIZZ system, Biosystèmes, Dijon, France). In cases where significant differences occurred, the means were compared by the Duncan test at the 0.05 level of probability.

\subsection{Chemical analysis}

$200 \mathrm{~g}$ of raw salmon flesh was homogenised in a Waring Blender (New Hartford, CO, USA). From $100 \mathrm{~g}$ of the homogenised milling, Total Volatile Basic Nitrogen (TVBN) and Trimethylamine (TMA) were measured in duplicate by the Conway micro diffusion method (Conway \& Byrne, 1933). The $\mathrm{pH}$ value was measured with a $\mathrm{pH}$ meter (Mettler Delta, AES, Combourg, France) in the five-fold-diluted flesh prepared as described below for microbiological analysis. 


\subsection{Enumeration of bacterial groups}

At each sampling date, three packets of two steaks per batch were used for microbiological analysis. From each package, a $10 \mathrm{~g}$ portion was aseptically weighed and the three portions were pooled in $120 \mathrm{ml}$ of sterile peptone water $(0.85 \% \mathrm{NaCl} ; 0.1 \%$ peptone $)$ in a sterile plastic bag and blended with a stomacher 400 (Seward Medical, London, UK) for 2 min. The different bacterial populations were enumerated by spread plating on the following media: Long and Hammer agar (LH) with $1 \% \mathrm{NaCl}$ (Van Spreekens, 1974) incubated at $15^{\circ} \mathrm{C}$ for 7 days to determine Total Psychrotrophic Viable Counts (TPVC); Elliker agar (Biokar Diagnostic, Beauvais, France) at $20^{\circ} \mathrm{C}$ for 3 days under anaerobic conditions (Anaerocult $A$; Merck, Darmstadt, Germany) to count total Lactic Acid Bacteria (LAB); Streptomycin sulphate Thallous Acetate Agar (STAA, Oxoid, Basingstoke England) to enumerate Brochothrix after 3 days at $20^{\circ} \mathrm{C}$. The $\mathrm{H}_{2} \mathrm{~S}$-producing bacteria were investigated in pour plates after 3 days at $20^{\circ} \mathrm{C}$ in Iron Agar (IA) with $0.04 \%$ of L-cysteine as described by Gram, et al (1987). Enterobacteriaceae were counted in a pour plate of Caso agar (Merck) overlaid by Violet Red Bile Glucose Agar (VRBGA, Biokar). called Caso/VRBG. and incubated for 2 days at $30^{\circ} \mathrm{C}$.

\subsection{Identification of bacterial isolates}

Isolation of bacteria was performed from spoiled salmon samples as follows: 22 isolates from each sample were randomly selected by picking colonies from plates of the highest dilution showing growth: 10 colonies from LH and 3 colonies from Elliker, IA, STAA and Caso/VRBG, respectively. 66 collected isolates were purified twice on brain heart infusion agar $(\mathrm{BHI}$, Biokar). Each isolate was then characterised for Gram reaction with $\mathrm{KOH}$ (Gregersen, 1978), catalase activity by the $3 \% \mathrm{H}_{2} \mathrm{O}_{2}$ method, and cytochrome oxidase production by Bactident Oxidase reagent (Merk, Darmstadt, Germany). The chromosomal DNA of 65 isolates was extracted using the Qiagen DNeasy Blood and Tissue Kit (Qiagen, S.A., Courtaboeuf, France). 16S rRNA gene was amplified by PCR with primers fD1 and rD1 (Table 1). All the oligonucleotide PCR primers used in this study were obtained from Invitrogen (Invitrogen, Cergy Pontoise, France) and are listed in Table 1. The PCR mixture $(50 \mu \mathrm{l})$ contained as final concentrations: $200 \mu \mathrm{mol} \mathrm{I}^{-1}$ of deoxynucleotide triphosphate mix (Interchim, Montluçon, France), $1 \times$ Taq buffer (10 mmol l-1 Tris- $\mathrm{HCl}\left[\mathrm{pH} \mathrm{9.0],} 50 \mathrm{mmol} \mathrm{l}^{-1} \mathrm{KCl}, 1.5 \mathrm{mmol} \mathrm{l}^{-1} \mathrm{MgCl}_{2}\right.$, $0.1 \%$ Triton X-100, $0.2 \mathrm{mg} / \mathrm{mL}$ BSA), $1.5 \mathrm{U}$ of Taq DNA polymerase (Interchim), $0.4 \mu \mathrm{mol} \mathrm{I}^{-1}$ of each primer, and $1 \mu \mathrm{L}$ of template DNA. PCR amplification was performed in a PTC-100 Thermocycler (MJ Research Inc., Watertown MA, USA) using the following protocol: initial denaturation $\left(94^{\circ} \mathrm{C}\right.$ for $\left.10 \mathrm{~min}\right)$, followed by 35 cycles of denaturation $\left(94^{\circ} \mathrm{C}\right.$ for $\left.1 \mathrm{~min}\right)$, primer annealing $\left(56^{\circ} \mathrm{C}\right.$ for $\left.1 \mathrm{~min} 15 \mathrm{sec}\right)$ and extension $\left(72^{\circ} \mathrm{C}\right.$ for $\left.1 \mathrm{~min} 15 \mathrm{sec}\right)$. A final extension at $72^{\circ} \mathrm{C}$ for 7 min was performed. PCR products were checked in a $1.5 \%(\mathrm{w} / \mathrm{v})$ agarose gel (Invitrogen) containing GelRed ${ }^{\mathrm{TM}}$ (FluoProbes ${ }^{\circledR}$, Interchim) $(0.5 \mathrm{X}$ ), and were subsequently visualised by UV illumination ImageMaster VDS-CL (Amersham, Pharmacia Biotech, Orsay, France). The PCR product length was evaluated with a DNA Ladder MassRuler'TM High range (\#SM0393) (Fermentas Life Science, Vilnius, Lithuania). The partial nucleotide sequence (about $700 \mathrm{bp}$ ) of the amplified 16S rRNA gene was determined with an automated sequencer (Beckman Coulter Genomics, Takeley, UK) using the internal primer SP1 (not published) for all 65 strains. The resulting sequences were then submitted to the Basic Local Alignment Search Tool program (BLAST) available at the National Center for Biotechnology Information (NCBI, Bethesda, USA, http://www.ncbi.nlm.nih.gov/) for representation of sequence and similarity searches in the GenBank database. For each group of strains identified as belonging to a bacterial species or genus by partial sequencing, the 16S rRNA gene was completely sequenced (about $1500 \mathrm{bp}$ ) for one or several representative strains of each group. Anticipated possible errors of sequencing reactions were corrected by sequencing both DNA strands with a set of 5 internal primers of the $16 \mathrm{~S}$ rRNA gene (not published). The 5 resulting sequences were assembled into a unique contig 
with BioEdit sequence alignment software (Hall, 1999). The contig sequences were then submitted to the National Center for Biotechnology Information.

\subsection{TTGE analysis}

\subsubsection{Direct bacterial DNA extraction from the salmon matrix}

The suspension prepared for bacteriological analysis was used to obtain molecular fingerprints from the salmon matrix. In order to separate the eukaryotic cells and DNA of salmon from the bacterial cells, $10 \mathrm{ml}$ of homogenised suspension was filtered on a Nucleospin Plant L column (Macherey-Nagel, Gutenberg, France) by centrifugation at 11700 $\mathrm{g}$ for $10 \mathrm{~min}$ at room temperature. The supernatant was carefully removed and the bacterial cell pellet was resuspended in $400 \mu \mathrm{L}$ of enzymatic lysis solution $(20 \mathrm{mM}$ Tris- $\mathrm{HCl}, \mathrm{pH}$ 8.0, 2 $\mathrm{mM}$ sodium EDTA, 1.2\% Triton $\mathrm{X}-100,20 \mathrm{mg} / \mathrm{ml}$ lysozyme, $11.6 \mathrm{U}$ mutanolysine) then transferred into a $2 \mathrm{ml}$ microtube and incubated at $37^{\circ} \mathrm{C}$ for $1 \mathrm{~h}$. A mechanical lysis step was then performed by addition of $0.3 \mathrm{~g}$ of glass beads (150 to $200 \mu \mathrm{m}$ diameter) and shaking during two cycles of 2 min in a bead beater MM200 (30 Hz) (Retsch, Haan, Germany). Proteins were digested by proteinase $\mathrm{K}(20 \mathrm{mg} / \mathrm{ml})$ with $200 \mu \mathrm{l}$ of AL buffer (DNeasy blood and tissue kit, Qiagen, Courtaboeuf, France) and incubated at $56^{\circ} \mathrm{C}$ for $30 \mathrm{~min}$. To pellet the glass beads, centrifugation at $9500 \mathrm{~g}$ for 3 min was carried out and the supernatant was transferred to a $2 \mathrm{ml}$ microtube to perform nucleic acid precipitation by addition of $200 \mu \mathrm{l}$ of ice-cold absolute ethanol. DNA purification was carried out using a DNeasy blood and tissue kit as described in the Qiagen instruction manual.

\subsubsection{PCR amplification}

The chromosomal DNA of the 65 strain isolates and bacterial DNA from the salmon matrix were analysed by PCR-TTGE.

Primers V3P2 and V3P3-GC-Clamp (Table 1) were used to amplify V3 region (194 bp) PCRamplicons as described previously (Jaffrès, et al., 2009). The size of the PCR products was determined in a 1.5\% (w/v) agarose gel (Invitrogen) using an exACTGene 100 bp PCR DNA Ladder (Fisher Scientific, Illkirch, France).

\subsubsection{TTGE gel analysis}

The PCR products obtained from the V3 $16 \mathrm{~S}$ rRNA gene fragment amplification were subjected to TTGE analysis. TTGE was performed using the DCode universal mutation detection system (BioRad, Marne-la-Coquette, France). Polyacrylamide gels, $16 \mathrm{~cm}$ by 16 $\mathrm{cm}$ by $1 \mathrm{~mm}$, were constructed with two layers including resolving and stacking gels. Resolving gels were prepared with 9.5\% (w/v) acrylamide stock solutions (acrylamidebisacrylamide; 37.5:1) and a final urea concentration of $8 \mathrm{M}$. Stacking gels were prepared without urea, with 16\% (w/v) acrylamide stock solutions (acrylamide-bisacrylamide; 37.5:1). Gels were prepared and run with 1.25X TAE buffer diluted from 50X TAE buffer (2 M Tris base, $1 \mathrm{M}$ glacial acetic acid, $50 \mathrm{mM}$ EDTA). Chemical polymerisation of acrylamide gels was initiated by ammonium persulphate and the quaternary amine $N, N, N^{\prime}, N^{\prime}-$ tetramethylethylenediamine (TEMED) after pouring into the vertical glass plate sandwich. Following polymerisation, gels were left overnight at $4^{\circ} \mathrm{C}$. Before loading the PCR products, the wells were rinsed with 1.25X TAE buffer. $30 \mu \mathrm{L}$ of PCR products with $1 \mathrm{X}$ of loading buffer were loaded onto wells. The electrophoresis run was performed at $50 \mathrm{~V}$ for $12 \mathrm{~h} 30 \mathrm{~min}$ with a temperature gradient of $65^{\circ} \mathrm{C}$ to $70^{\circ} \mathrm{C}$ (rate of $0.4^{\circ} \mathrm{C}$. h-1) under stirring with a magnetic 
stirrer to mix the buffer and improve the temperature gradient homogeneity (Ogier, et al., 2002). After the run, gels were rinsed for $20 \mathrm{~min}$ in Milli-Q water (Millipore, Molsheim, France), stained for $30 \mathrm{~min}$ in $300 \mathrm{ml}$ of $3 X$ GelRed $^{\mathrm{TM}}$ staining solution (FluoProbes ${ }^{\circledR}$, Interchim) in $\mathrm{H}_{2} \mathrm{O}$ with $0.1 \mathrm{M} \mathrm{NaCl}$, then rinsed for 20 min in Milli-Q water and photographed by UV illumination ImageMaster VDS-CL (Amersham).

\subsubsection{TTGE ladder and fingerprint analysis}

Standardisation, analysis and comparison of TTGE fingerprints were monitored using BioNumerics Software, version 6.0 (Applied Maths NV, Sint-Martens-Latem, Belgium). A TTGE ladder was prepared by pooling the V3 amplicons of DNA obtained from pure cultures of 10 bacterial strains chosen to produce fingerprints spread over the gel. The software standardises TTGE profiles to minimise migration differences between gels by alignment of the ladders in the different gels.

\subsubsection{TTGE fragment cloning and sequencing}

Bands excised from TTGE gels using a sterile blade were eluted in $200 \mu$ of Milli-Q water. The eluted DNA $(10 \mu \mathrm{l})$ was re-amplified with primers V3P2 and V3P3-GC-Clamp and the amplicons were subjected to TTGE analysis to confirm their relative positions. The eluted DNA was then re-amplified with primers V3P2 and V3P1 (V3P3 lacking the GC clamp) (Table 1). PCR products were then purified with the MinElute PCR Purification Kit (Qiagen) and cloned in the $\mathrm{pCR}^{\circledR} 4-\mathrm{TOPO}^{\circledR}$ vector then transformed in chemically competent Escherichia coli DH5 $\alpha$, using the TOPO TA cloning kit (Invitrogen). Cloning of the PCR products was necessary because TTGE analysis revealed weak bands in addition to the excised bands after re-amplification (Ogier, et al., 2002). Between 5 and 10 clones were selected for each excised band and these were submitted to plasmid DNA extraction with a Qiaprep Miniprep kit (Qiagen). A PCR amplification of cloned fragments was then carried out with V3P3 and V3P2 primers and the amplicons were subjected to another TTGE to select the positive clones that contained specifically the $\mathrm{V} 3$ fragment corresponding to the excised band without artefact bands. Cloned insert sequencing with M13 reverse and T7 P forward primers, sequence comparison and phylogenetic analyses were conducted as described above.

\section{Results}

\subsection{Sensory characteristics of raw salmon}

After 3 days of storage, batches B, A and C were considered as "non-spoiled" by $100 \%$, $90.9 \%$ and $72.7 \%$ of the panellists, respectively (Table 2 ). At day 7 , the level "strongly spoiled" was used by 72.7 to $100 \%$ of the panellists, according to the batch. At the end of storage, batch $\mathrm{C}$ seemed less strongly spoiled compared to day 7; however, the three batches were still evaluated "highly spoiled" by more than $50 \%$ of the panellists.

The evolution of the degree of spoilage was associated with different odour characteristics as illustrated in Table 2. At the beginning of storage (day 3), the three batches presented a rather low overall odour intensity, mainly characterised by marine and grass odours. After 7 days, the overall odour intensity increased in the three samples and the characteristics of fresh salmon (marine, grass) were replaced by new odours, qualified as acid, sour and amine, related to spoilage. Batches kept these odour characteristics after 10 days of storage. 
Compared to batches $\mathrm{A}$ and $\mathrm{C}$, batch $\mathrm{B}$ also presented a significantly higher note of cheese/feet and had a tendency to develop the acid note less.

\subsection{Chemical analysis}

Total volatile basic nitrogen (TVBN) and trimethylamine (TMA) production are shown in Figs. 1 and 2, respectively. TVBN levels did not exceed $15 \mathrm{mg}-\mathrm{N}$ TVBN $100 \mathrm{~g}^{-1}$ until 3 days of storage for all the batches. After 7 days of storage, the production reached about $22 \mathrm{mg}-\mathrm{N}$ TVBN $100 \mathrm{~g}^{-1}$ for batch A and $26 \mathrm{mg}-\mathrm{N}$ TVBN $100 \mathrm{~g}^{-1}$ for the other two batches. The highest production was observed at the end of the storage period, attaining about $30 \mathrm{mg}-\mathrm{N}$ TVBN $100 \mathrm{~g}^{-1}$, for the 3 batches.

Up to 3 days of storage, no TMA production was found in batches $A$ and $C$ and the initial content in batch $B$ was below $3 \mathrm{mg}-\mathrm{N}$ TMA $100 \mathrm{~g}^{-1}$. In the spoiled products, the production rose by nearly 10 for all the batches. The maximal TMA level was observed at the end of storage for the 3 batches reaching approximately 12 to 14 mg-N TMA $100 \mathrm{~g}^{-1}$.

\subsection{Enumeration of the different bacterial groups}

After 3 days of storage at $2^{\circ} \mathrm{C}$, all the batches presented a relatively variable contamination level. In batch A, the different flora did not exceed 3 Log CFU. . $^{-1}$. In batches B and C, TPVC reached approximately 5 Log CFU. ${ }^{-1}$ and the other flora did not present a count higher than about 3 Log CFU. $g^{-1}$ except for LAB (5 Log CFU. $g^{-1}$ ) in batch C. The latter appeared to be the most initially contaminated batch.

At day 7, when all the batches were spoiled, the microbiota of the three batches greatly increased and presented the same contamination level with almost 8.5 Log CFU. g $^{-1}$ for the TPVC (Figure 3 ). The main part of the flora consisted of LAB, which reached a value of 7.5 Log CFU. g $^{-1}$ in batches A and B and 9 Log CFU. g $^{-1}$ in batch C. Batches A and B presented the same level of Brochothrix with approximately 6 Log CFU. $\mathrm{g}^{-1}$ while it was about $4.5 \mathrm{Log}$ CFU. $\mathrm{g}^{-1}$ in batch C. Enterobacteriaceae counts were higher in batches B and C, $6.5 \mathrm{Log}$ CFU. g $^{-1}$ and 7.0 Log CFU. L $^{-1}$ respectively, and only 5.3 Log CFU. L $^{-1}$ in batch $\mathrm{A} . \mathrm{H}_{2} \mathrm{~S}$ producing bacteria reached 3.5 Log CFU. $\mathrm{g}^{-1}$ in batch A and 5.3 Log CFU. ${ }^{-1}$ in the other two batches .

Finally, microbiota levels remained quite constant until the end of storage (day 10) for the three batches.

\subsection{Identification of bacterial isolates}

The phenotypic tests (Gram reaction, oxidase, catalase) grouped 65 isolates out of 66 from the 3 batches (only 1 isolate never grew in laboratory conditions in $\mathrm{BHI}$ broth). These were divided into 43 Gram-negative bacteria with 38 "oxidase-negative" and 5 "oxidase-positive" isolates. An appreciable proportion of Gram-positive bacteria were also found with 22 isolates including the LAB group showing catalase-negative reactions (12 isolates) and the catalase-positive group (10 isolates).

The isolates were identified by 16S rRNA gene partial sequencing and distributed into 15 different genera or species (Table 3). The Gram-negative bacteria were mainly identified as Serratia spp. (21 isolates, 13 of them were identified at species level as Serratia proteamaculans) and Photobacterium phosphoreum (18 isolates). Using total 16S rRNA gene sequencing, 4 of the $13 \mathrm{~S}$. proteamaculans isolates were confirmed as $S$. proteamaculans and 3 of the Serratia spp. isolates were identified as Serratia quinivorans. Concerning the $P$. phosphoreum isolates, the total 16S rRNA gene was sequenced for 3 of them. However, the results did not discriminate between $P$. phosphoreum and 
$P$. iliopiscarium. In fact, these two species cannot be distinguished by $16 \mathrm{~S}$ rRNA gene comparison. This observation has already been made by Ast and Dunlap (2005). The last 4 Gram-negative isolates identified by total sequencing were 3 Enterobacteriaceae (Yersinia intermedia, Hafnia alvei, Buttiauxella gaviniae) and 1 Pseudomonas sp..

The LAB group contained isolates identified by partial sequencing as Carnobacterium maltaromaticum (4), Carnobacterium divergens (2), Lactococcus piscium (3), Lactobacillus fuchuensis (1), Vagococcus sp. (1) and Leuconostoc gasicomitatum (1). The 10 strains belonging to the Gram-positive and catalase-positive group were identified at species level as Brochothrix thermosphacta. Identification results were confirmed by total 16S rRNA gene sequencing for 2 isolates of C. maltaromaticum, 2 C. divergens, 1 LC. piscium, 1 Lb. fuschuensis, 2 B. thermosphacta and $1 \mathrm{Ln}$. gasicomitatum. Using this technique, the Vagoccocus sp. isolate was. tentatively identified at species level as $\mathrm{V}$. carniphilus.

\subsection{TTGE analysis}

TTGE analysis enabled the dynamics of the microbiota to be visualised by examining fingerprints of the dominating bacterial groups evolving during storage (Figure 4). In order to analyse the TTGE patterns and to detect the presence of bacterial species, fingerprints of the different samples were compared with those of pure strains isolated from these batches: $C$. maltaromaticum, C. divergens, B. thermosphacta, LC. piscium and P. phosphoreum. These strains isolated from the spoiled salmon batches belong to species whose patterns are already known. In fact, these species are present in different seafood products and have already been studied by PCR-TTGE in our laboratory.

By comparing band migration positions, 7 bands (from Lp1 to Lp7) could be assigned as LC. piscium, 7 others as $P$. phosphoreum (Pp1 to Pp7) and the weak band Bt1 as B. thermosphacta.

In some cases, when no assignation was possible with known profiles or for weak band assignation, the identification was performed by cloning and sequencing of the gel-excised bands. Using cloning, bands corresponding to Pseudomonas sp. were identified in all the batches (cloned bands Ps1, Ps2 and Ps3) while the weak band Bt1 was confirmed as Brochothrix sp. In the different batches, bands Pp1, Pp3, Pp4 and Pp8 were confirmed as $P$. phosphoreum and bands Lp3 and Lp6 corresponded to Lc. piscium.

For each batch, a different profile was observed between samples stored for 3 days and those stored for 7 or 10 days, which both presented the same profile. At day 3, batch A was characterised by the presence of Pseudomonas and Brochothrix. Some weak bands could correspond to $P$. phosphoreum although this was not confirmed by cloning. The profile observed at day 3 for batch $B$ was quite similar with an additional band clearly identified as P. phosphoreum. Batch C showed a different profile with LC. piscium and Pseudomonas. An unidentified band was detected in the three samples and disappeared in each case at days 7 and 10.

At day 7 and day 10, Pseudomonas was no longer detected in the three batches whereas Lc. piscium and $P$. phosphoreum were observed. A weak band could be assigned to $B$. thermosphacta in sample A7 and another one to C. maltaromaticum in sample B7 but this one was not confirmed by cloning. 


\section{Discussion}

Several studies have been devoted to raw salmon, notably on the effect of MAP on the shelf life duration (Sivertsvik, et al., 2002), but the bacterial ecosystem has not yet been thoroughly described. In the present work, changes in the sensory quality of fresh salmon packed under MAP and vacuum were assessed by sensory analysis and the composition of its microbiota was studied using culture-dependent and culture-independent approaches. The sequence of the storage temperatures was inspired by the shelf life validation protocol used by professionals. This protocol mimicked the route followed by the product from the store to the consumer's fridge.

Regarding sensory analysis results, the 3 salmon steak batches were considered strongly spoiled after 7 days of storage although, according to the suppliers, the batches had a shelf life of 8 days. This is an example of the quality problem appearing with non-compliant products rejected before the use-by-date. The point of sensory rejection of raw salmon under MAP has been studied in several works and the shelf life is variable, mainly depending on the temperature of storage and the $\mathrm{CO}_{2}$ concentration: 5 days for salmon steaks under MAP $\left(60 \% \mathrm{CO}_{2}-40 \% \mathrm{~N}_{2}\right)$ stored at $5^{\circ} \mathrm{C}, 3$ days for those stored at $10^{\circ} \mathrm{C}$ and 17 days for salmon fillets stored at $2^{\circ} \mathrm{C}$ (Sivertsvik, et al., 2002). Emborg, et al. (2002) found a shelf life of 14 and 21 days for two salmon steak batches under MAP $\left(60 \% \mathrm{CO}_{2}-40 \% \mathrm{~N}_{2}\right)$ stored at $2^{\circ} \mathrm{C}$.

After 7 days, amine and sour odours were described as the main sensory characteristics of spoilage of the 3 batches studied here, corresponding to results obtained in previous studies (Emborg, et al., 2002; Hansen, et al., 2009). Moreover, acid/vinegar was also perceived in our samples. After 10 days of storage, a significant cheese/feet odour was detected in batch $B$ but not in the others. This sensory characteristic could possibly be due to its different type of packaging (under vacuum) although Hansen, et al. (2009) did not detect differences in characteristic odours for spoiled salmon under MAP or vacuum.

According to European Community regulation $n^{\circ} 2074 / 2005((E C), 2005)$, the TVBN limit for Atlantic salmon is $35 \mathrm{mg}-\mathrm{N}$ TVBN $100 \mathrm{~g}^{-1}$. Although the highest production of TVBN in the 3 batches is below this value (about $30 \mathrm{mg}^{-\mathrm{N}}$ TVBN $100 \mathrm{~g}^{-1}$ ), they were considered strongly spoiled. It has already been shown that this parameter, often used as a spoilage quality indicator for seafood kept on ice, displays lower values for fish stored in a $\mathrm{CO}_{2}$ atmosphere and considered spoiled by sensory analysis (Sivertsvik, et al., 2002). There is no regulation concerning the TMA level but beyond $12 \mathrm{mg}-\mathrm{N}$ TMA $100 \mathrm{~g}^{-1}$, the product quality is generally considered damaged. After 7 days of storage, when the 3 batches were rejected by the panellists, none of the batches tested here exceeded this limit. Our results confirm that levels of TVBN or TMA are not closely linked to the sensory quality of salmonid fish stored under MAP or vacuum.

The initial microbial contamination level of fresh MAP salmon batches, between 3 and 5 Log CFU. $g^{-1}$ for TPVC, was similar to those found in previous studies: 3 Log CFU.g ${ }^{-1}$ (Schirmer, et al., 2009) and about 4 Log CFU.g ${ }^{-1}$ (Fletcher, et al., 2002). Batch C, which presented the highest initial bacterial number, also spoiled fastest confirming that initial contamination is a crucial parameter to control in order to ensure shelf life. When the 3 batches were considered spoiled (7 days), the TPVC reached its maximal value of 8.5 Log CFU. g $^{-1}$. However, spoilage does not depend only on the high level of contamination but rather on which microorganisms are present on the product. Indeed, the spoilage microflora is made up of microorganisms that have actively contributed to the spoilage, called Specific Spoilage Organisms (SSO), and microorganisms that have grown without affecting the sensory quality (Gram, et al., 2002). Nevertheless, SSO have to be present at least at 7 Log CFU.g ${ }^{-1}$ to produce enough metabolites responsible for spoilage. Plate count results at spoilage time (day 7) presented TPVC and LAB as the main flora for the 3 batches followed by 
Enterobacteriaceae for batches $\mathrm{B}$ and $\mathrm{C}$. Some previous studies have already demonstrated that $\mathrm{CO}_{2}$ packaging allows the growth of $\mathrm{LAB}$ with an association of Gram-negative fermentative bacteria such as P. phosphoreum (Gram \& Dalgaard, 2002; Gram, et al., 2002; Sivertsvik, et al., 2002). In vacuum packaging, like under MAP, the microflora typically becomes dominated by $L A B$ and Gram-negative fermentative bacteria, including psychrotrophic Enterobacteriaceae, in addition to some species of Shewanella capable of anaerobic respiration (Gram \& Huss, 1996). Most of these bacterial groups cited above were found in the isolates picked from Petri plates at the time of spoilage. Identification of the 30 TPVC isolates from LH showed a majority of Gram-negative bacteria (26/30 isolates), in particular $P$. phosphoreum (18 isolates) and Enterobacteriaceae (8 isolates) like Serratia sp..The latter (21 isolates, including $13 \mathrm{~S}$. proteamaculans and $3 \mathrm{~S}$. quinivorans) were also isolated from CASO/VRBG and IA. Among our isolates, there was also a significant proportion of Gram-positive bacteria with a majority of $B$. thermosphacta and LAB such as $C$. maltaromaticum, C. divergens, Lc. piscium, $L b$. fuchuensis, $V$. carniphilus and $L n$. gasicomitatum. LAB isolates were found for the most part on Elliker media but also on IA media. Indeed, the $\mathrm{H}_{2} \mathrm{~S}$-producing isolates were identified as LAB (3 isolates) and Enterobacteriaceae (6 isolates) although this medium was made to detect Shewanella sp. (Gram, et al., 1987).

In our study, no real differences were observed between MAP and vacuum-packed batches either in the bacterial counts or in isolate identification or in PCR-TTGE profiles.

TTGE and DGGE techniques were used to display changes within the bacterial community due to temperature variation, changes in atmosphere, etc... PCR-TTGE enabled the dominant bacterial species present in the products to be highlighted and microbiota dynamics to be observed in our batches. Major visible species represented from 1\% to $100 \%$ of the total flora ((Jaffrès, et al., 2009; Ogier, et al., 2002)). For each batch, the main switch in flora observed between sample stored for 3 days and the other two stored for 7 and 10 days was probably due to the packaging (under MAP or vacuum) and the temperature change during storage. Indeed, day 3 samples were stored at $2^{\circ} \mathrm{C}$ whereas day 7 and day 10 samples both underwent a cold chain break $\left(2\right.$ hours at $\left.20^{\circ} \mathrm{C}\right)$ and spent the end of storage at $8^{\circ} \mathrm{C}$.

Using TTGE, we have shown that Pseudomonas sp. was one of the major microflora detected in the 3-day samples at the beginning of storage and was no longer detected from day 7. Under aerobic storage, the microflora of fish from temperate water is dominated by psychrotrophic aerobic Gram-negative bacteria, in particular Pseudomonas sp. and S. putrefaciens (Gram \& Huss, 1996; Sivertsvik, et al., 2002). It is well known that $\mathrm{CO}_{2}$ packaging inhibits these bacteria in fish and meat products (Gram \& Huss, 1996; Mastromatteo, et al., 2010; Mastromatteo, et al., 2009; Reynisson, et al., 2009) explaining why they were not detected by TTGE in our batches and few were identified among the isolates at the time of spoilage.

B. thermosphacta was identified but only in batch $A$. This result is in accordance with bacterial counts showing that this species, accounting for less than $1 \%$ of TPVC, was not dominant.

After 7 days of storage, a turnover was observed in all the spoiled matrices tested in favour of $L C$. piscium and $P$. phosphoreum. Identification of these two species as main flora by PCR-TTGE is in agreement with the culture results obtained. LC. piscium belonging to LAB was enumerated on Elliker and LAB were found as the major bacterial group present on the samples while $P$. phosphoreum was one of the main species identified in the TPVC isolates.

In previous works, it has been observed that sometimes multiple bands occur for a single species and can result in an overestimate of the number of species present in complex 
ecosystems (Ogier, et al., 2002; Parayre, et al., 2007). In pure culture, $P$. phosphoreum showed several main bands: 5 main bands in PCR-DGGE (Hovda, et al., 2007). In this study, $P$. phosphoreum pure strain presented four main bands. Moreover, on the TTGE profile of batch $\mathrm{C}$ stored for 7 days, one band (Pp8) identified as $P$. phosphoreum had a different migration position compared to other darker bands identified as $P$. phosphoreum (bands Pp1 to Pp7). This phenomenon can be explained by the presence of several ribosomal genes with sequence heterogeneity (Parayre, et al., 2007).

We can suppose that some of the predominating bacterial groups present at the time of spoilage play a role in product deterioration. In previous studies, $P$. phosphoreum has been identified as the SSO responsible for TMA production and spoilage of MAP cod in Denmark (Dalgaard, 1995; Dalgaard, et al., 1993). This organism is also likely to be of importance for spoilage of several MAP marine fish species stored at chilled temperature (Dalgaard, et al., 1997). In fresh MAP salmon stored between 1 and $2^{\circ} \mathrm{C}, P$. phosphoreum has been observed as the dominating spoilage microflora (Emborg, et al., 2002; Hansen, et al., 2009) and as an SSO responsible for the spoilage of this product. $P$. phosphoreum was identified as one of the bacterial microbiota in farmed halibut by PCR-DGGE methods (Hovda, et al., 2007). Reynisson, et al. (2009) also confirmed the importance of $P$. phosphoreum as a spoilage organism during storage of cod loins at low temperature using molecular techniques. Moreover, this recent study also revealed that the high predominance of $P$. phosphoreum was observed in all cod samples tested under MAP and air except in the newly packaged samples, which were dominated by Sphingomonas spp. and Pseudomonas fluorescens.

S. proteamaculans is known as a typical spoilage bacterium of vacuum-packed pork and beef meat (Ercolini, et al., 2009; Schirmer \& Langsrud, 2010) and it has also been identified in seafood like cold smoked salmon (Joffraud, et al., 2006; Stohr, et al., 2001), processed fresh edible sea urchin microbiota (Kajikazawa, et al., 2007), and cooked tropical shrimps (Jaffrès, et al., 2011; Jaffrès, et al., 2009). A previous investigation on salmon steaks stored at $2^{\circ} \mathrm{C}$ under $\mathrm{CO}_{2}$ /air (40/60, v/v) atmosphere showed that Gram-positive bacteria such as LAB and Brochothrix were dominating the spoilage flora (de la Hoz, et al., 2000). More precisely, Rudi, et al. (2004) observed C. maltaromaticum, C. divergens and $B$. thermosphacta as the dominant flora in salmon fillets packed in an atmosphere consisting of $60 \% \mathrm{CO}_{2}$ and $40 \% \mathrm{~N}_{2}$ stored for 12 days at $5^{\circ} \mathrm{C}$ and 18 days at $1^{\circ} \mathrm{C}$. Jaffrès, et al. (2009) described major Gram-positive flora on cooked tropical shrimps. Some strains of $C$. maltaromaticum are already known for their spoilage abilities on different products (meat, seafood products) (Afzal, et al., 2010; Leisner, et al., 2007; Leroi, 2010), conversely some C. divergens have shown their ability to inhibit growth of pathogens such as Listeria monocytogenes (Brillet, et al., 2005; Duffes, et al., 2000) and C. maltaromaticum is used for technological aspects in cheese (Afzal, et al., 2010). A few strains of Lc. piscium are of interest in seafood biopreservation (Matamoros, et al., 2009). It is notable that this study demonstrates the presence of $V$. carniphilus in seafood. This strain has been isolated in meat (Shewmaker, et al., 2004) but Jaffrès, et al. (2010, 2009) have also identified some isolates as $V$. carniphilus, $V$. fluvialis and the new species $V$. penaei in cooked shrimp.

\section{Conclusion}

To our knowledge, this is the first report using PCR-TTGE to compare the predominant bacterial composition and diversity in Atlantic salmon.

Combining sensory analysis, conventional microbial and culture-independent methods, the spoilage microbiota of these 3 raw salmon batches have been described in this study. Different groups or species have been identified as the main spoilage association bacteria like LAB (LC. piscium), Gram-negative fermentative bacteria ( $P$. phosphoreum) and 
Enterobacteriaceae (Serratia spp.). Some of them have been detected by one type of method or by both. In this work, the traditional microbial techniques enabled the bacterial genus or species diversity to be appreciated more precisely than with the PCR-TTGE method. However, the latter technique confirmed the identification results obtained and enabled the dominant species and their dynamics during storage, due to the temperature changes and the packaging, MAP or vacuum, to be displayed.

This approach has improved our knowledge of the bacterial populations present, their dominance and their dynamics in spoiled raw salmon steaks packed under MAP or vacuum.

\section{Acknowledgements}

This study was carried out as part of the MIPROMER program, managed by Pôle Agronomique Ouest (PAO). Sabrina Mace's PhD thesis is financially supported by the Bretagne and Pays de la Loire regions and by Oniris (Nantes). We are grateful to STBM department members, Christophe Mesnard, Sandrine Bruzac and Claire Donnay Moreno, for chemical analyses.

\section{References}

(EC), C. R. (2005). No 2074/2005 of 5 December 2005 laying down implementing measures for certain products under Regulation.

AFNOR (1987). Normalisation française. Analyse sensorielle. Directives générales pour l'implantation de locaux destinés à l'analyse sensorielle V09-105.

Afzal, M. I., Jacquet, T., Delaunay, S., Borges, F., Milliere, J. B., Revol-Junelles, A. M., \& Cailliez-Grimal, C. (2010). Carnobacterium maltaromaticum: identification, isolation tools, ecology and technological aspects in dairy products. Food Microbiol, 27(5), 573-579.

Ast, J. C., \& Dunlap, P. V. (2005). Phylogenetic resolution and habitat specificity of members of the Photobacterium phosphoreum species group. Environmental Microbiology, 7, 1641-1654.

Brillet, A., Pilet, M. F., Prevost, H., Cardinal, M., \& Leroi, F. (2005). Effect of inoculation of Carnobacterium divergens $\mathrm{V} 41$, a bio-preservative strain against Listeria monocytogenes risk, on the microbiological, chemical and sensory quality of coldsmoked salmon. Int J Food Microbiol, 104(3), 309-324.

Conway, E. J., \& Byrne, A. (1933). An absorption apparatus for the micro-determination of certain volatile substances: The micro-determination of ammonia. Biochem J, 27(2), 419-429.

Dalgaard, P. (1995). Modelling of microbial activity and prediction of shelf life for packed fresh fish. Int J Food Microbiol, 26(3), 305-317.

Dalgaard, P., Gram, L., \& Huss, H. H. (1993). Spoilage and shelf-life of cod fillets packed in vacuum or modified atmospheres. Int J Food Microbiol, 19(4), 283-294.

Dalgaard, P., Mejholm, O., Christiansen, T. J., \& Huss, H. H. (1997). Importance of Photobacterium phosphoreum in relation to spoilage of modified atmosphere-packed fish products. Letters in Applied Microbiology, 24(5), 373-378.

de la Hoz, L., Lopez-Galvez, D. E., Fernandez, M., Hierro, E., \& Ordonez, J. A. (2000). Use of carbon dioxide enriched atmospheres in the refrigerated storage (2 degrees C) of salmon (Salmo salar) steaks. European Food Research and Technology, 210(3), 179-188. 
Duffes, F., Leroi, F., Dousset, X., \& Boyaval, P. (2000). Use of a bacteriocin producing Carnobacterium piscicola strain, isolated from fish, to control Listeria monocytogenes development in vacuum-packed cold-smoked salmon stored at 4 degrees C. Sciences Des Aliments, 20(1), 153-158.

Emborg, J., Laursen, B. G., Rathjen, T., \& Dalgaard, P. (2002). Microbial spoilage and formation of biogenic amines in fresh and thawed modified atmosphere-packed salmon (Salmo salar) at 2 degrees C. J Appl Microbiol, 92(4), 790-799.

Ercolini, D., Russo, F., Nasi, A., Ferranti, P., \& Villani, F. (2009). Mesophilic and psychrotrophic bacteria from meat and their spoilage potential in vitro and in beef. Appl Environ Microbiol, 75(7), 1990-2001.

FAO (2011). Fisheries and Aquaculture Information and Statistics Service

FAO. (C) 2004-2011. Texte par Jones, M. I. R. (2004). Programme d'Information sur les espèces aquatiques cultivées. Salmo salar. Département des pêches et de l'aquaculture de la FAO [en ligne].

Fletcher, G. C., Summers, G., Corrigan, V., Cumarasamy, S., \& Dufour, J. P. (2002). Spoilage of king salmon (Oncorhynchus tshawytscha) fillets stored under different atmospheres. [Article]. Journal of Food Science, 67(6), 2362-2374.

Giacomazzi, S., Leroi, F., L'Henaff, C., \& Joffraud, J. J. (2004). rpoB-PCR amplified gene and temporal temperature gradient gel electrophoresis: a rapid tool to analyse bacterial strains representative of cold-smoked salmon microflora. Letters in Applied Microbiology, 38, 130-134.

Gram, L., \& Dalgaard, P. (2002). Fish spoilage bacteria--problems and solutions. Curr Opin Biotechnol, 13(3), 262-266.

Gram, L., \& Huss, H. H. (1996). Microbiological spoilage of fish and fish products. Int J Food Microbiol, 33(1), 121-137.

Gram, L., Ravn, L., Rasch, M., Bruhn, J. B., Christensen, A. B., \& Givskov, M. (2002). Food spoilage - interactions between food spoilage bacteria. [Proceedings Paper]. International Journal of Food Microbiology, 78(1-2), 79-97.

Gram, L., Trolle, G., \& Huss, H. H. (1987). Detection of specific spoilage bacteria from fish stored at low $\left(0^{\circ} \mathrm{C}\right)$ and high $\left(20^{\circ}\right)$ temperatures. International Journal of Food Microbiology, 4, 65-72.

Gregersen, T. (1978). Rapid method for distinction of gram-negative from gram-positive bacteria. Applied Microbiology and Biotechnology, 5(2), 123-127.

Hall, T. A. (1999). BioEdit: a user-friendly biological sequence alignment editor and analysis program for Windows 95/98/NT. Nucleic Acids Symp Ser 41, 95-98.

Hansen, A. A., Morkore, T., Rudi, K., Olsen, E., \& Eie, T. (2007). Quality changes during refrigerated storage of MA-packaged pre-rigor fillets of farmed Atlantic cod (Gadus morhua L.) using traditional MAP, CO2 emitter, and vacuum. Journal of Food Science, 72(9), 423-430.

Hansen, A. A., Morkore, T., Rudi, K., Rodbotten, M., Bjerke, F., \& Eie, T. (2009). Quality Changes of Prerigor Filleted Atlantic Salmon (Salmo salar L.) Packaged in Modified Atmosphere Using CO2 Emitter, Traditional MAP, and Vacuum. Journal of Food Science, 74(6), M242-M249.

Hovda, M. B., Sivertsvik, M., Lunestad, B. T., Lorentzen, G., \& Rosnes, J. T. (2007). Characterisation of the dominant bacterial population in modified atmosphere packaged farmed halibut (Hippoglossus hippoglossus) based on 16S rRNA geneDGGE. Food Microbiol, 24(4), 362-371.

ISO, I. O. f. S. ( 2003). Sensory Analysis, Methodology. General Guidance for Establishing a Sensory Profile, ISO 13299, Geneva, Switzerland

Jaffrès, E., Lalanne, V., Macé, S., Cornet, J., Cardinal, M., Sérot, T., Dousset, X., \& Joffraud, J.-J. (2011). Sensory characteristics of spoilage and volatile compounds associated with bacteria isolated from cooked and peeled tropical shrimps using SPME-GC-MS analysis. International Journal of Food Microbiology, 147(3), 195-202. 
Jaffrès, E., Prévost, H., Rossero, A., Joffraud, J. J., \& Dousset, X. (2010). Vagococcus penaei sp. nov., isolated from spoilage microbiota of cooked shrimp (Penaeus vannamei). Int J Syst Evol Microbiol, 60(Pt 9), 2159-2164.

Jaffrès, E., Sohier, D., Leroi, F., Pilet, M. F., Prévost, H., Joffraud, J. J., \& Dousset, X. (2009). Study of the bacterial ecosystem in tropical cooked and peeled shrimps using a polyphasic approach. Int J Food Microbiol, 131(1), 20-29.

Joffraud, J. J., Cardinal, M., Cornet, J., Chasles, J. S., Leon, S., Gigout, F., \& Leroi, F. (2006). Effect of bacterial interactions on the spoilage of cold-smoked salmon. Int $\mathrm{J}$ Food Microbiol, 112(1), 51-61.

Juste, A., Thomma, B., \& Lievens, B. (2008). Recent advances in molecular techniques to study microbial communities in food-associated matrices and processes. Food Microbiology, 25(6), 745-761.

Kajikazawa, T., Sugita, T., \& Nishikawa, A. (2007). Comprehensive identification of bacteria in processed fresh edible sea urchin using $16 \mathrm{~S}$ ribosomal DNA sequence analysis: The products contain various food poisoning-related bacteria and opportunistic bacterial pathogens. Journal of Health Science, 53(6), 756-759.

Lafarge, V., Ogier, J. C., Girard, V., Maladen, V., Leveau, J. Y., Gruss, A., \& DelacroixBuchet, A. (2004). Raw cow milk bacterial population shifts attributable to refrigeration. Appl Environ Microbiol, 70(9), 5644-5650.

Leisner, J. J., Laursen, B. G., Prevost, H., Drider, D., \& Dalgaard, P. (2007). Carnobacterium: positive and negative effects in the environment and in foods. FEMS Microbiol Rev, 31(5), 592-613.

Leroi, F. (2010). Occurrence and role of lactic acid bacteria in seafood products. Food Microbiology, 27(6), 698-709.

Mastromatteo, M., Danza, A., Conte, A., Muratore, G., \& Del Nobile, M. A. (2010). Shelf life of ready to use peeled shrimps as affected by thymol essential oil and modified atmosphere packaging. International Journal of Food Microbiology, 144(2), 250-256.

Mastromatteo, M., Lucera, A., Sinigaglia, M., \& Corbo, M. R. (2009). Microbiological characteristics of poultry patties in relation to packaging atmospheres. International Journal of Food Science and Technology, 44(12), 2620-2628.

Matamoros, S., Leroi, F., Cardinal, M., Gigout, F., Kasbi Chadli, F., Cornet, J., Prevost, H., \& Pilett, M. F. (2009). Psychrotrophic lactic acid bacteria used to improve the safety and quality of vacuum-packaged cooked and peeled tropical shrimp and cold-smoked salmon. J Food Prot, 72(2), 365-374.

Ogier, J. C., Lafarge, V., Girard, V., Rault, A., Maladen, V., Gruss, A., Leveau, J. Y., \& Delacroix-Buchet, A. (2004). Molecular fingerprinting of dairy microbial ecosystems by use of temporal temperature and denaturing gradient gel electrophoresis. Appl Environ Microbiol, 70(9), 5628-5643.

Ogier, J. C., Son, O., Gruss, A., Tailliez, P., \& Delacroix-Buchet, A. (2002). Identification of the bacterial microflora in dairy products by temporal temperature gradient gel electrophoresis. Appl Environ Microbiol, 68(8), 3691-3701.

Parayre, S., Falentin, H., Madec, M. N., Sivieri, K., Le Dizes, A. S., Sohier, D., \& Lortal, S. (2007). Easy DNA extraction method and optimisation of PCR-Temporal Temperature Gel Electrophoresis to identify the predominant high and low GC-content bacteria from dairy products. J Microbiol Methods, 69(3), 431-441.

Pennacchia, C., Ercolini, D., \& Villani, F. (2011). Spoilage-related microbiota associated with chilled beef stored in air or vacuum pack. Food Microbiology, 28(1), 84-93.

Rachman, C., Fourrier, A., Sy, A., De La Cochetiere, M. F., Prevost, H., \& Dousset, X. (2004). Monitoring of bacterial evolution and molecular identification of lactic acid bacteria in smoked salmon during storage. Le Lait, 84, 145-154.

Reynisson, E., Lauzon, H. L., Magnusson, H., Jonsdottir, R., Olafsdottir, G., Marteinsson, V., \& Hreggvidsson, G. O. (2009). Bacterial composition and succession during storage of North-Atlantic cod (Gadus morhua) at superchilled temperatures. BMC Microbiol, 9, 250. 
Rudi, K., Maugesten, T., Hannevik, S. E., \& Nissen, H. (2004). Explorative multivariate analyses of 16S rRNA gene data from microbial communities in modifiedatmosphere-packed salmon and coalfish. Applied and Environmental Microbiology, 70(8), 5010-5018.

Schirmer, B. C., Heiberg, R., Eie, T., Moretro, T., Maugesten, T., Carlehog, M., \& Langsrud, S. (2009). A novel packaging method with a dissolving $\mathrm{CO}_{2}$ headspace combined with organic acids prolongs the shelf life of fresh salmon. Int J Food Microbiol, 133(12), 154-160.

Schirmer, B. C., \& Langsrud, S. (2010). Evaluation of Natural Antimicrobials on Typical Meat Spoilage Bacteria In Vitro and in Vacuum-Packed Pork Meat. Journal of Food Science, 75(2), M98-M102.

Shewmaker, P. L., Steigerwalt, A. G., Morey, R. E., Carvalho, M. D., Elliott, J. A., Joyce, K., Barrett, T. J., Teixeira, L. M., \& Facklam, R. R. (2004). Vagococcus carniphilus sp nov., isolated from ground beef. International Journal of Systematic and Evolutionary Microbiology, 54, 1505-1510.

Sivertsvik, M., Jeksrud, J., \& Rosnes, J. T. (2002). A review of modified atmosphere packaging of fish and fishery products - significance of microbial growth, activities and safety. International Journal of Food Science and Technology, 37(2), 107-127.

Sivertsvik, M., Rosnes, J. T., \& Kleiberg, G. H. (2003). Effect of Modified Atmosphere Packaging and Superchilled Storage on the Microbial and Sensory Quality of Atlantic Salmon (Salmo salar) Fillets. Journal of Food Science, 68(4), 1467-1472.

Stohr, V., Joffraud, J. J., Cardinal, M., \& Leroi, F. (2001). Spoilage potential and sensory profile associated with bacteria isolated from cold-smoked salmon. Food Research International, 34(9), 797-806.

Van Spreekens, K. (1974). The suitability of Long and Hammer's medium for the enumeration of more fastidious bacteria from fresh fishery products. Archiv für Lebensmittelhygiene, 25, 213 - 219.

Weisburg, W. G., Barns, S. M., Pelletier, D. A., \& Lane, D. J. (1991). 16S ribosomal DNA amplification for phylogenetic study. J Bacteriol, 173(2), 697-703. 


\section{Tables}

Table 1: Sequences of oligonucleotide primers used for PCR amplification.

\begin{tabular}{|c|c|c|c|c|}
\hline Primer & Position & Oligonucleotide sequence $\left(5^{\prime} \rightarrow 3^{\prime}\right)$ & $\begin{array}{l}\text { Annealing } \\
\left({ }^{\circ} \mathrm{C}\right)\end{array}$ & Reference \\
\hline fD1 & 16S rDNA gene, forward (positions 8 to 27). & AGAGTTTGATCCTGGCTCAG & 56 & (Weisburg, et al., 1991) \\
\hline rD1 & 16S rDNA gene, reverse (positions 1525 to 1542). & TAAGGAGGTGATCCAGCC & 56 & (Weisburg, et al., 1991) \\
\hline V3P1 & 16S rDNA gene, forward (positions 340 to 356). & CCTACGGGAGGCAGCAG & 62 & (Parayre, et al., 2007) \\
\hline V3P2 & 16S rDNA gene, forward (positions 517 to 533). & ATTACCGCGGCTGCTGG & 62 & (Parayre, et al., 2007) \\
\hline V3P3 & $\begin{array}{l}\text { 16S rDNA gene, forward (positions } 340 \text { to 356) } \\
\text { with GC clamp. }\end{array}$ & $\begin{array}{l}\text { CGCCCGCCGCGCGCGGCGGGCGGGGCGG } \\
\text { GGGCACGGGGGCCTACGGGAGGCAGCAG }\end{array}$ & 62 & (Parayre, et al., 2007) \\
\hline
\end{tabular}


Table 2: Spoilage level and sensory characteristics of three raw salmon batches: $A$ and $C$ (packaged under MAP), B (packaged under vacuum), after 7 days of refrigerated storage $\left(2^{\circ} \mathrm{C}\right.$ for 3 days, break of 2 hours at $20^{\circ} \mathrm{C}$ and $8^{\circ} \mathrm{C}$ for 4 days).

\begin{tabular}{|c|c|c|c|c|c|c|c|c|c|c|}
\hline & & \multicolumn{3}{|c|}{3 days } & \multicolumn{3}{|c|}{7 days } & \multicolumn{3}{|c|}{10 days } \\
\hline & & A & B & C & A & B & C & A & B & C \\
\hline \multirow{3}{*}{ Level $^{1}$} & non-spoiled & 90.9 & 100 & 72.7 & 0 & 0 & 0 & 0 & 0 & 0 \\
\hline & lightly spoiled & 9.1 & 0 & 27.3 & 27.3 & 9.1 & 0 & 36.4 & 9.1 & 45.5 \\
\hline & strongly spoiled & 0 & 0 & 0 & 72.7 & 90.9 & 100 & 63.6 & 90.9 & 54.5 \\
\hline \multirow{8}{*}{ Characteristics $^{2}$} & overall intensity & 3.85 & 3.01 & 3.48 & 6.85 & 7.2 & 7.26 & 6.14 & 7.2 & 6.2 \\
\hline & marine & 2.71 & 1.99 & 1.6 & 0.45 & 0.35 & 0.39 & 0.82 & 0.5 & 0.4 \\
\hline & grass & 1.62 & 2.16 & 0.82 & 0.21 & 0.33 & 0.24 & 0.41 & 0.39 & 0.28 \\
\hline & butter & 0.23 & 0.16 & 0.52 & 0.56 & 0.45 & 0.88 & 0.62 & 0.4 & 0.53 \\
\hline & acid & 0.15 & 0.08 & 0.15 & 2.53 & 2.94 & 2.92 & 2.25 & 1.45 & 3.34 \\
\hline & sour & 0.2 & 0.16 & 0.16 & 3.47 & 4.68 & 4.75 & 4.06 & 3.45 & 3.47 \\
\hline & amine & 0.05 & 0.06 & 0.06 & 3.4 & 3.57 & 3.11 & 2.06 & 2.71 & 2.92 \\
\hline & feet/cheese ${ }^{3}$ & 0.08 & 0.11 & 0.07 & 0.73 & 0.9 & 1.23 & $0.53 \mathrm{~b}$ & $2.94 \mathrm{a}$ & $1.29 \mathrm{~b}$ \\
\hline
\end{tabular}

${ }^{1}$ Percentage of panellists in each category of spoilage

${ }^{2}$ Panel mean score for each sensory characteristic and each product (continuous scale from 0 to 10 )

${ }^{3}$ Different superscript letters indicate significant differences between samples by two-way ANOVA and multiple comparison test LSD $(p<0.05)$ and Duncan's multiple comparison test $(p<0.05)$. 
Table 3: Identification and medium origin of the bacterial strains isolated from the 3 spoiled raw salmon batches; A and C (packaged under MAP), B (packaged under vacuum).

\begin{tabular}{|c|c|c|c|c|c|c|c|c|c|c|c|c|c|c|c|c|}
\hline \multirow[b]{2}{*}{ IDENTIFICATION } & \multicolumn{5}{|c|}{ Batch A } & \multicolumn{5}{|c|}{ Batch B } & \multicolumn{5}{|c|}{ Batch C } & \multirow[b]{2}{*}{ TOTAL } \\
\hline & $\mathrm{LH}$ & ELK & IA & STAA & $\begin{array}{c}\text { Caso } \\
\text { VRBG }\end{array}$ & $\mathrm{LH}$ & ELK & IA & STAA & $\begin{array}{c}\text { Caso } \\
\text { VRBG }\end{array}$ & $\mathrm{LH}$ & ELK & IA & STAA & $\begin{array}{c}\text { Caso } \\
\text { VRBG }\end{array}$ & \\
\hline Photobacterium phosphoreum & 7 & & & & & 5 & & & & & 6 & & & & & 18 \\
\hline Serratia proteamaculans & & & 1 & & 2 & 3 & & 1 & & 1 & & & 3 & & 2 & 13 \\
\hline Serratia quinivorans & & & & & 1 & 1 & & & & 1 & & & & & & 3 \\
\hline Serratia sp. & & & & & & & 1 & & & 1 & 3 & & & & & 5 \\
\hline Yersinia intermedia & 1 & & & & & & & & & & & & & & & 1 \\
\hline Buttiauxella gaviniae & & & & & & & & 1 & & & & & & & & 1 \\
\hline Hafnia alvei & & & & & & & & & & & & & & & 1 & 1 \\
\hline Pseudomonas sp. & & & & & & & & & 1 & & & & & & & 1 \\
\hline Brochothrix thermosphacta & 2 & & & 3 & & & & & 2 & & & & & 3 & & 10 \\
\hline Carnobacterium maltaromaticum & & & 1 & & & 1 & 1 & 1 & & & & & & & & 4 \\
\hline Carnobacterium divergens & & 2 & & & & & & & & & & & & & & 2 \\
\hline Lactococcus piscium & & 1 & & & & & & & & & & 2 & & & & 3 \\
\hline Vagococcus carniphilus & & & 1 & & & & & & & & & & & & & 1 \\
\hline Leuconostoc gasicomitatum & & & & & & & & & & & 1 & & & & & 1 \\
\hline Lactobacillus fuchuensis & & & & & & & & & & & & 1 & & & & 1 \\
\hline
\end{tabular}

LH: Long and Hammer agar

ELK: Elliker agar

IA: Iron Agar

STAA: Streptomycin sulphate Thallous Acetate Agar

Caso VRBG: Caso agar VRBG: Violet Red Bile Glucose agar 


\section{Figures}

Figure 1: Total volatile base nitrogen (TVBN) production (mg-N $100 \mathrm{~g}^{-1}$ ) in 3 batches of raw salmon packed under modified atmosphere ( $A$ and $C$ ) and under vacuum (B), after 3,7 or 10 days of refrigerated storage $\left(2^{\circ} \mathrm{C}\right.$ for 3 days, break of 2 hours at $20^{\circ} \mathrm{C}$ and $8^{\circ} \mathrm{C}$ for 4 days).

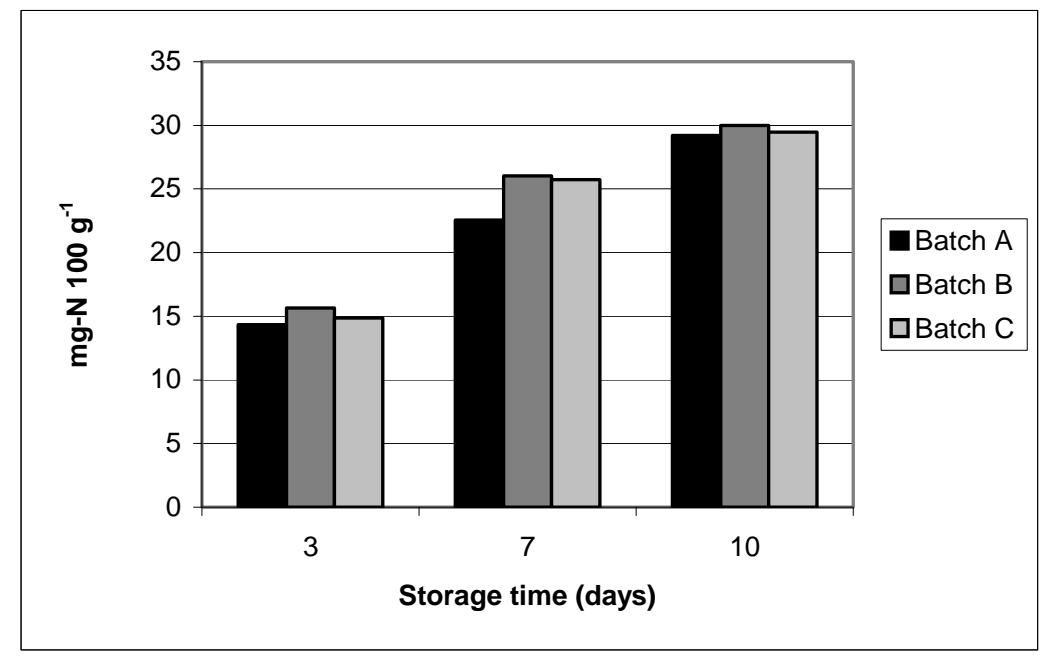

Figure 2: Trimethylamine (TMA) production ( $\mathrm{mg}-\mathrm{N} 100 \mathrm{~g}^{-1}$ ) in 3 batches of raw salmon packed under modified atmosphere (A and $C$ ) and under vacuum (B), after 3, 7 or 10 days of refrigerated storage $\left(2^{\circ} \mathrm{C}\right.$ for 3 days, break of 2 hours at $20^{\circ} \mathrm{C}$ and $8^{\circ} \mathrm{C}$ for 4 days).

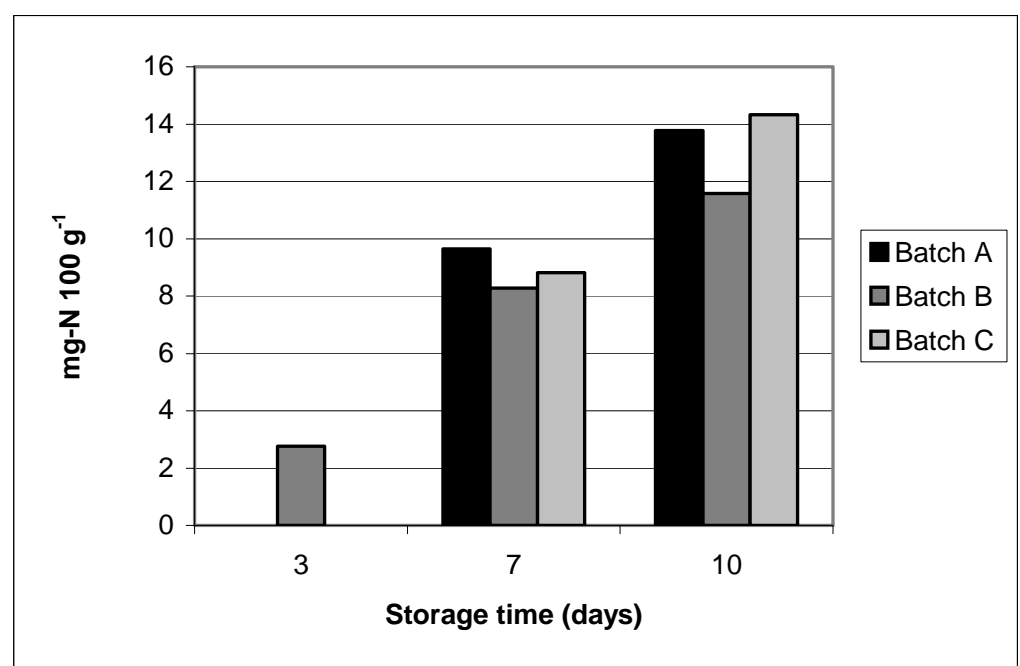


Figure 3: Changes in bacterial counts in the three batches of raw salmon: $A$ and $C$ (packaged under MAP), B (packaged under vacuum), after 7 days of refrigerated storage $\left(2^{\circ} \mathrm{C}\right.$ for 3 days, break of 2 hours at $20^{\circ} \mathrm{C}$ and $8^{\circ} \mathrm{C}$ for 4 days).

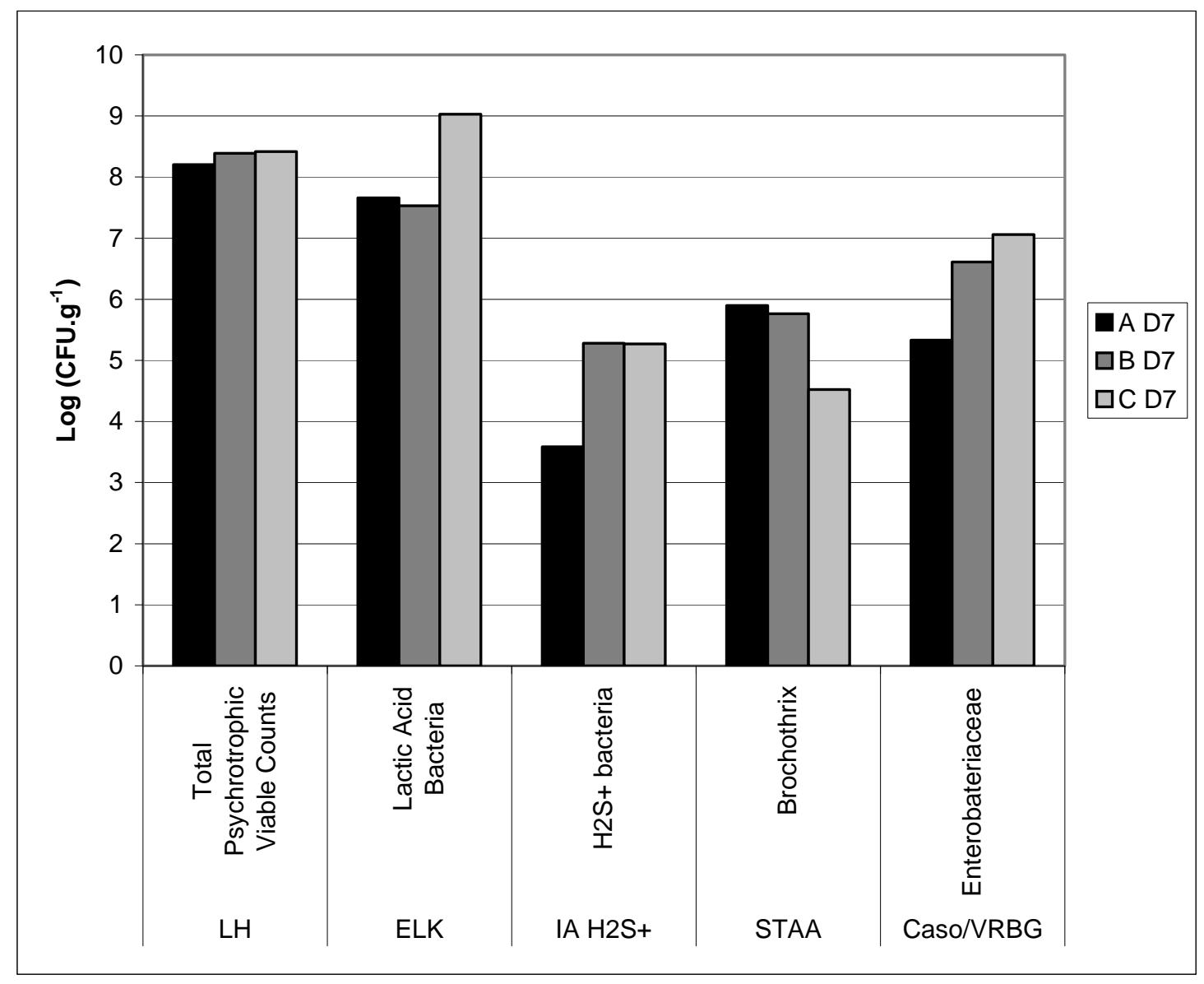


Figure 4: Fingerprints and bacterial population dynamics of raw salmon during storage Digitized TTGE profiles of $16 \mathrm{~S}$ rRNA gene $\mathrm{V} 3$ regions obtained by PCR amplification from bacterial DNA of three samples (day 3 , day 7 , day 10 ) from 3 different batches $(A ; B ; C$ ) stored at $2^{\circ} \mathrm{C}$ for 3 days, then 2 hours at $20^{\circ} \mathrm{C}$ and finally at $8^{\circ} \mathrm{C}$ for 7 days. Lanes $L C$. piscium; C. maltaromaticum; C. divergens, B. thermosphacta; P. phosphoreum: profiles of pure strain isolated from the salmon batches. Lanes A3 to C10: salmon matrix profiles from batches $A, B$, and $C$, respectively, obtained for each day of analysis. Excised band identification obtained by sequencing and cloning V3 fragment $(99-100 \%$ Identity in Blastn/NCBI): Ps1, Ps2, and Ps3, Pseudomonas sp.; Bt 1 (weak band present but not visible on this figure), identified as Brochothrix sp.; Pp1, Pp3, Pp4 and Pp8, P. phosphoreum; Lp3 and Lp6, Lc piscium; *, cloned bands with no identification results. Bands Lp1, Lp2, Lp4, Lp5, Lp7 have been assigned as Lc. piscium and Pp2, Pp5, Pp7 as $P$. phosphoreum by comparison with pure strain profiles. Vertical lines represent band classes determined from the genera/species specific TGGE fingerprint

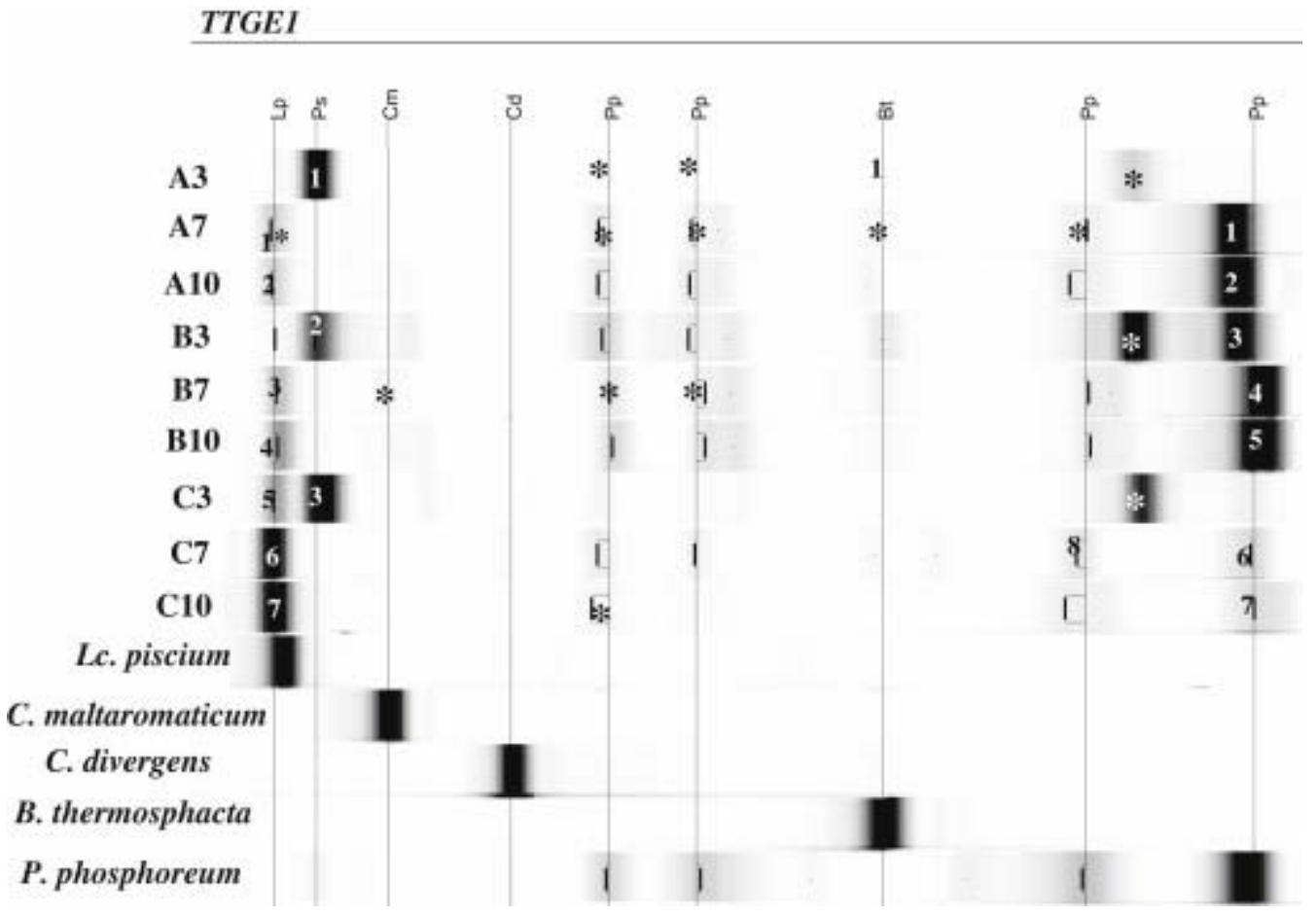

